\title{
Arginine Dihydrolase Activity in Species of the Genus Bacillus Revealed by Thin-layer Chromatography
}

\author{
By J. C. G. OTTOW* \\ Fachbereich Biologie, Institut für Mikrobiologie, Technische Hochschule, \\ Darmstadt, Germany
}

(Received 7 February 1974; revised 8 April 1974)

INTRODUCTION

The arginine dihydrolase system catalyses the hydrolysis of arginine into ornithine, $\mathrm{NH}_{3}$ and $\mathrm{CO}_{2}$ with a gain of ATP:

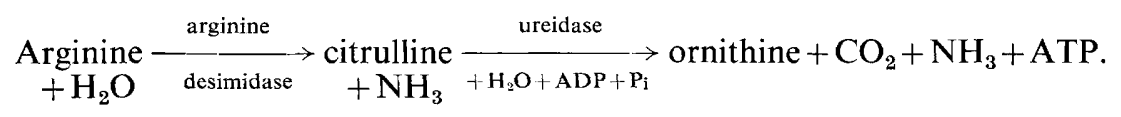

This reaction may occur under anaerobic conditions thus providing a means for aerobic organisms to generate energy in the absence of free oxygen.

Arginine dihydrolase is detected in routine laboratory tests by the anaerobic tube method of Thornley (1960) or by one of its modifications (Taylor \& Whitby, I964; Stewart, I97I; Jagnow, I973). Stanier, Palleroni \& Doudoroff (I966) detected this enzyme activity by measuring the disappearance of arginine in phosphate buffer. However, all these procedures have been developed for Gram-negative, non-fermentative bacteria (particularly Pseudomonas species) but have not yet been applied to Gram-positive organisms. Preliminary studies with some Bacillus strains revealed unsatisfactory and misleading results with Thornley's anaerobic tube method, caused by an alkaline shift in the medium as a result of deamination and/or decarboxylation rather than arginine dihydrolase activity. Thin-layer chromatography for the detection of the arginine dihydrolase system proved suitable in species of Pseudomonas (Zolg \& Ottow, 1973). Therefore this method was adapted to detect this system in species of Bacillus.

\section{METHODS}

Organisms. The 169 Bacillus strains and their sources are listed in Table I. These strains represent 3I different Bacillus species and include strains of ten new species described after the publication of Bergey's Manual of Determinative Bacteriology (1957). The morphological grouping of these new species has been recorded by Ottow (1974).

Media. All strains were grown at $\mathrm{pH} 6.8$ on a fortified nutrient agar (Steinigeweg \& Ottow, 1974). The pH was adjusted to $6 \cdot 0$ for cultivation of Bacillus pulvifaciens CIP53I 39 . The strains received as $B$. laevolacticus and B. racemilacticus were maintained on the glucoseacetate agar (pH 6.2) of Nakayama \& Yanoshi (I967). The B. fastidiosus strains were cultivated on the nutrient agar supplemented with allantoin $(20 \mathrm{~g} / 1)$.

Incubation temperature. Unless otherwise stated, all cultures were incubated at $28{ }^{\circ} \mathrm{C}$. Strains of $B$. coagulans, B. circulans, B. laevolacticus, B. pantothenticus, B. pulvifaciens and

* Present address: Abteilung für Bodenchemie und Biochemie, Fachgruppe Ökologische Standortskunde der Universität, 7000 Stuttgart-Hohenheim, Germany. 
Table I. Occurrence of arginine dehydrolase system among Bacillus species

Breakdown products were detected on thin-layer chromatograms after $3 \mathrm{~h}$ incubation of a thick cell suspension in a tube containing $0.5 \mathrm{ml} \mathrm{L}$-arginine-hydrochloride $(0.01 \mathrm{M}, \mathrm{pH} 6.4)$ solution.
Organisms
Citrulline Ornithine
Organisms
Citrulline Ornithine

Group I*

B. badius

CCM2II 3

B. coagulans

CCMIO2

CCM2OI 3

B. cereus

CCM2010

ILMI 3, 14

CCM98

Jo $48-5$ I

B. cereus var. mycoides CCMI 45

Jo $13,15,31,32,36$,

$37,55,72,75,79$, I00,

I 1 7, I 20-1 25, I 27-1 36,

$138-40$

CCM43 I

Jo $6,8-12,17,18,25$,

$52-55,103,132$

B. firmus

CCM22I 2

CCM37

CCM2213

B. insolitus

ATCC23299

$B$. lentus

CCM35

CCM22I 4

B. licheniformis

CCM864

CCM21 45

SMGI 4

JO24

JO25

JO26

B. macquariensis NCTCIO420

B. maroccanus

ATCC25099

B. medusa

ATCC2562 I

B. megaterium

CCMI 462

ILMI 9

Jo $4,5,6$, I I, 12

B. pacificus

ATCC 25098

B. psychrophilus ATCC23304

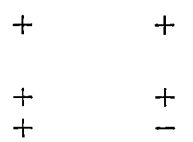

$\begin{array}{ll}+ & + \\ + & + \\ + & +\end{array}$

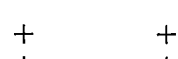

$+\quad+$
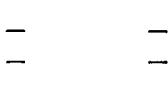

$+\quad+$

- -

$+\quad+$

- -

$+\quad+$

$+\quad+$

$+\quad+$

-

$+\quad+$

-

$+\quad+$

$+\quad+$

$+\quad+$

$+\quad+$

rat

$+$
Group I* (cont.)

B. pumilus

CCM340

CCM2 I 44

SMG 27

SMG296

ILMI 5

jo $36-38$

B. subtilis

CCMI 7 I 8

CCM221 6

SMGIO

ILMI 8

JO2O

JO2 I

$\mathrm{JO22}$

JO23

$B$. thuringiensis

CCMI9

ILMI 7, 18

JO $30-35$

$\begin{array}{ll}+ & + \\ + & + \\ + & + \\ + & + \\ + & +\end{array}$

Group II*

B. alvei

CCMI6I 4

CCM205I

SMG29

SMG3O5

ILM2 I

JO39

J040

JO4 I

JO42

B. brevis

CCMIO89

CCM2050

SMG 298

B. circulans

SMGI I

SMG329

CCM2048

ILM42

JO43

J044

JO45

JO46

J047

$\begin{array}{ll}- & + \\ - & + \\ + & + \\ + & + \\ + & + \\ + & + \\ + & +\end{array}$

$\begin{array}{ll}+ & + \\ + & + \\ + & +\end{array}$

B. globisporus ATCC2330I

B. laevolacticus

ATCC23492

ATCC23493
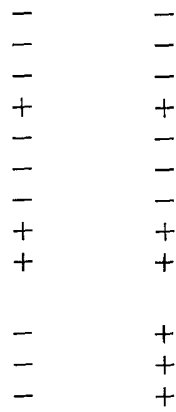

$\begin{array}{ll}- & + \\ = & + \\ = & - \\ = & - \\ = & - \\ + & + \\ + & +\end{array}$

$+$


Table I (cont.)

Organisms Citrulline Ornithine Organisms Citrulline Ornithine

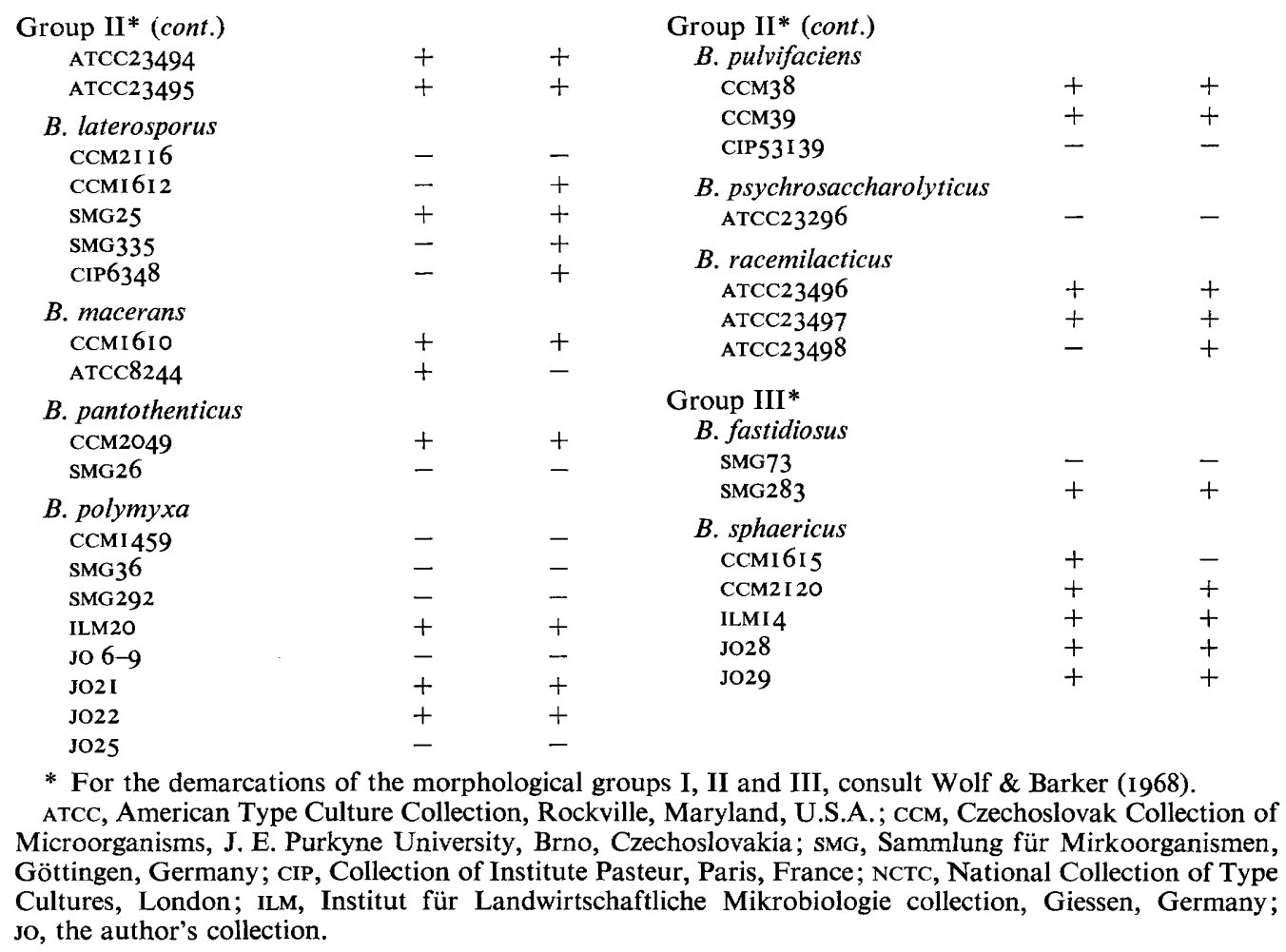

B. racemilacticus were tested at $37^{\circ} \mathrm{C}$, those received as B. globisporus, B. macquariensis, $B$. pacificus, B. psychrophilus and B. psychrosaccharolyticus were kept at $20^{\circ} \mathrm{C}$.

Arginine dihydrolase assay. One loopful of each culture (24 to $48 \mathrm{~h})$ was transferred into $0.5 \mathrm{ml}$ of sterile $0.0 \mathrm{I} \mathrm{M} \mathrm{L-arginine} \mathrm{solution} \mathrm{(} \mathrm{pH} \mathrm{6.4}$ ), incubated for $3 \mathrm{~h}$ at $20^{\circ} \mathrm{C}$ (room temperature) or $37^{\circ} \mathrm{C}$ (stationary, in a waterbath), respectively, and centrifuged ( $15 \mathrm{~min}$ at $2600 \mathrm{~g}$ ). Clear supernatant ( $2 \mu \mathrm{l}$ ) was applied to $0.2 \mathrm{~mm}$ cellulose layers ('Avicel' cellulose, Merck AG, Darmstadt, Germany) and chromatograms run with $n$-butanol-acetonediethylamine-water (I0: I0:2:5) (Arx \& Neher, 1963) as a solvent system. Each chromatogram included $2 \mu \mathrm{l}$ samples of $0.0 \mathrm{I} \mathrm{M}$ aqueous solutions of arginine, citrulline, ornithine and putrescine. Air-dried chromatograms were sprayed with a $\mathrm{I} \%$ ninhydrin solution in isopropanol. After heating the chromatograms (I min at $90^{\circ} \mathrm{C}$ ) all compounds mentioned gave purple spots. This method is essentially as described by Zolg \& Ottow (I973).

\section{RESULTS AND DISCUSSION}

The average $R_{F}$-values obtained were: arginine, 0.04 , citrulline, 0.18 , ornithine, 0.29 and putrescine, $0 \cdot 77$, enabling the amino acids and the amine to be clearly separated.

In Table $\mathrm{I}$ the distribution of the arginine dihydrolase system among the Bacillus species is listed according to the classification of the various species in one of the three morphological groups of Wolf \& Barker (I968). Within the positive strains, the majority produced both 
citrulline (the intermediate product) and ornithine (the end product). Only a few strains revealed ornithine or citrulline alone. These observations are ascribed respectively to (i) complete conversion of arginine to ornithine and (ii) incomplete hydrolysis, within the $3 \mathrm{~h}$ period. Strains that produced citrulline only were retested with the incubation time increased to $5 \mathrm{~h}$. Under these conditions, all originally 'incomplete' strains (B. coagulans CCM2013, B. macerans CCM20I2, B. sphaericus CCMI6I5 and B. subtilis ILMI8) showed both citrulline and ornithine, although with different intensities. Generally speaking, the positıve strains of $B$. cereus, $B$. cereus var. mycoides and $B$. thuringiensis revealed a weak dihydrolase activity, whereas fair to good activity was recorded with $B$. brevis, B. licheniformis, B. laevolacticus, $B$. megaterium, B. subtilis and B. sphaericus, if judged by the intensities of the spots. By far the most intense ornithine spot was observed with $B$. licheniformis J025, suggesting a complete hydrolysis of arginine within the $3 \mathrm{~h}$ period.

Bacillus strains that did not metabolize arginine in the first experiments, were also reincubated for the extended incubation time. However, neither citrulline nor ornithine could be detected.

Putrescine, which may be produced from ornithine by decarboxylation (ornithine decarboxylase, EC. 4.I.I.I7), was never observed on the chromatograms of arginine dihydrolase-positive bacilli, in contrast to Pseudomonas species that revealed both ornithine and putrescine on chromatograms (Zolg \& Ottow, I973), suggesting the presence of both arginine dihydrolase and ornithine decarboxylase. Only in $B$. cereus var. mycoides soroo and jor 30 , characterized by the production of brown and yellow exo-pigments respectively, purplebrown spots $\left(R_{F}=0.56\right)$ were observed additionally on the chromatograms. These spots may have been the unknown pigments.

From these results the following overall conclusions are drawn. Firstly, the arginine dihydrolase enzyme system is widely distributed in aerobic spore-formers; out of I69 different Bacillus strains, I 26 (about $75 \%$ ) were capable of catabolizing arginine. Secondly, this hydrolytic enzyme is not restricted to any of the three morphological groups within the genus Bacillus. Thirdly, with some species, all strains tested produced arginine dihydrolase or lacked this enzyme complex.

Among the species that had four (or more) strains tested only those belonging to $B$. laevolacticus, B. megaterium, B. pumilus, B. sphaericus and $B$. thuringiensis all gave positive tests. Most species showed both positive and negative strains. In fact, the absence rather than the presence of the arginine dihydrolase system in certain species (B. lentus, B. maquariensis, B. pacificus, B. globisporus and B. psychrosaccharolyticus) may prove to be of taxonomic value. However, a more comparative study is needed for the evaluation of the importance of this arginine dihydrolase test in the classification of the genus Bacillus.

I wish to express my gratitude to the following for sending their strains: Dr B. Delaporte, Laboratoire Botanique, Paris, France; Dr A. von Klopotek, Institut für Landwirtschaftliche Mikrobiologie, University of Giessen, Germany; Dr B. Stewart, CSIRO, Division of Food Preservation, North Ryde, Australia; Professor J. A. Larkin, Department of Microbiology, Louisiana State University, Baton Rouge, U.S.A.; Professor O. Nakayama, Department of Biotechnology, Yamanaki University, Kofu, Japan; and Dr H. de Barjac, Institut Pasteur, Paris. 


\section{REFERENCES}

ARX, E. \& NEHER, R. (1963). Eine multidimensionale Technik zur chromatographischen Identifikation von Aminosäuren. Journal of Chromatography 12, 329-34I.

Bergey's Manual of Determinative Bacteriology, 7 th edn. (1957). Edited by R. S. Breed, E. G. D. Murray and N. R. Smith. Baltimore: Williams and Wilkins.

JAGNOW, G. (1973). Eine Verbesserung des Testmediums für Arginin-Dihydrolase bei Pseudomonaden aus Boden und die Anwendungsmöglichkeit für serienmäßige 'multi-point' Beimpfung in kleinen Gefäßßen. Soil Biology International News Bulletin 17, I I-13.

NAKAYAMA, O. \& YANOSHI, M. (1967). Spore-bearing lactic bacteria isolated from rhizosphere. Journal of General and Applied Microbiology 13, 139-153.

Oттоw, J. C. G. (I974). Detection of hippurate hydrolase among Bacillus species by thin layer chromatography and other methods. Journal of Applied Bacteriology 37 (in the Press).

Stanier, R. Y., Palleroni, N. J. \& Doudoroff, M. (I966). The aerobic pseudomonas: a taxonomic study. Journal of General Microbiology 43, I59-27I.

SteinigeweG, R. \& Ottow, J. C. G. (I974). Nachweismethoden und Verbreitung der Pektinolyse bei Bacillus-Arten. Zeitschrift für Allgemeine Mikrobiologie (in the Press).

StewART, D. J. (197I). A composite arginine glucose medium for the characterization of Pseudomonas aeruginosa and other Gram-negative bacilli. Journal of Applied Bacteriology 34, 779-786.

TAYLOR, J. J. \& WHITBY, J. L. (I964). Pseudomonas pyocyanea and the arginine dihydrolase system. Journal of Clinical Pathology 17, I22-125.

Thornley, M. J. (1960). The differentiation of Pseudomonas from other Gram-negative bacteria on the basis of arginine metabolism. Journal of Applied Bacteriology 23, 37-52.

Wolf, J. \& BARKer, A. N. (1968). The genus Bacillus: aids to the identification of its species. In Identification Methods for Microbiologists Part B, pp. 93-109. Edited by B. M. Gibbs and D. A. Shapton. London and New York: Academic Press.

ZolG, W. \& OTtow, J. C. G. (1973). An improved thin-layer technique for detection of arginine dihydrolase among Pseudomonas species. Applied Microbiology 26, I00I-1003. 